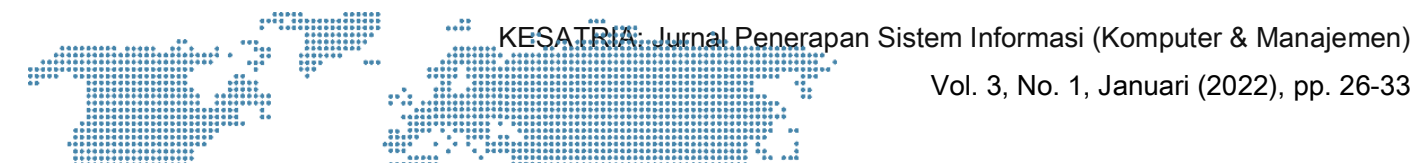

\title{
Aplikasi Media Dembelajaram Pendidikan Agama Kristen Untuk Anäk-Anak Sekolah Minggu Berbasis Android (Studi Kasus Gereja Toraja Jemaat Ora Et Labora Lagia)

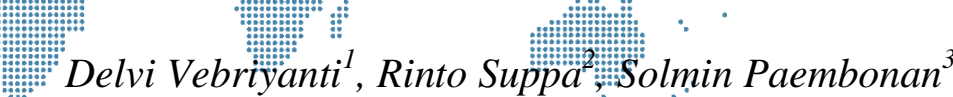 \\ ${ }^{1,2,3}$ Universitas Andi Djemma Pälopo, Palopo \\ delfyvebriyanti@gmail.com ${ }^{1}$, rintosuppa@gmail.com ${ }^{2}$,
} \\ solminpaembonan@gmail.com
}

\begin{abstract}
This review intends to plan and fabricate an Android-based Christian Strict Instruction Learning Media Application at the Ora Et Labora Lagia Toraja Church. The exploration strategy utilized is a subjective strategy with information assortment methods utilizing perception, meetings, and writing studies. This learning media application was created utilizing the Cascade Framework improvement technique. The product utilized in the plan and execution of the framework involves Adobe Streak Proficient CS6 as the framework plan. Christian strict training learning media applications incorporate Sunday school materials, tests, and youngsters' profound melodies. The application that has been assembled has been tried on clients so an application that runs well is acquired
\end{abstract}

Keywords : Learning Media, Christian Education.

\begin{abstract}
Abstrak
Kajian ini bertujuan untuk merencanakan dan membuat Aplikasi Media Pembelajaran Tegas Kristen Berbasis Android di Gereja Ora Et Labora Lagia Toraja. Strategi eksplorasi yang digunakan adalah strategi subyektif dengan metode pengumpulan informasi menggunakan studi persepsi, pertemuan, dan tulisan. Aplikasi media pembelajaran ini dibuat dengan memanfaatkan teknik perbaikan Cascade Framework. Produk yang digunakan dalam perencanaan dan pelaksanaan kerangka kerja melibatkan Adobe Streak Proficient CS6 sebagai rancangan kerangka kerja. Aplikasi media pembelajaran pelatihan ketat kristen menggabungkan materi sekolah minggu, tes, dan melodi anak-anak yang mendalam. Aplikasi yang telah dirakit telah dicoba pada klien sehingga diperoleh aplikasi yang berjalan dengan baik.
\end{abstract}

Kata Kunci : Media Pembelajaran, Pendidikan Kristen

\section{Pendahuluan}

Pendidikan bagi anak-anak kristen selain dilakukan di sekolah juga dilakukan setiap hari minggu di gereja yang didalamnya terdapat proses belajar mengajar yang berkaitan dengan kekristenan. Proses belajar mengajar di sekolah minggu dilakukan dengan berbagai cara yang tentunya berbeda dengan cara belajar di sekolah pada umumnya. Metode penyampaian materi di sekolah minggu sekarang ini sudah sangat bervariasi. Di beberapa gereja dibagian kota telah banyak memakai alat elektronik serta memadukan berbagai cara belajar yang diharapkan dapat mengundang minat belajar para anak di Gereja. Pembelajaran, hubungan pengajar dan pelajar dapat berjalan dengan baik dan efesien apabila memakai media dalam belajar. Dalam pembelajaran media memiliki beberapa fungsi salah satunya yaitu berfungsi dalam membantu guru dalam menyampaikan materi atau cerita [1].

Dari penelitian yang telah dilakukan, ditemukan kendala yang dihadapi oleh pengajar sekolah minggu di Gereja Toraja Jemaat Ora Et Labora Lagia. Kendala yang dihadapi 


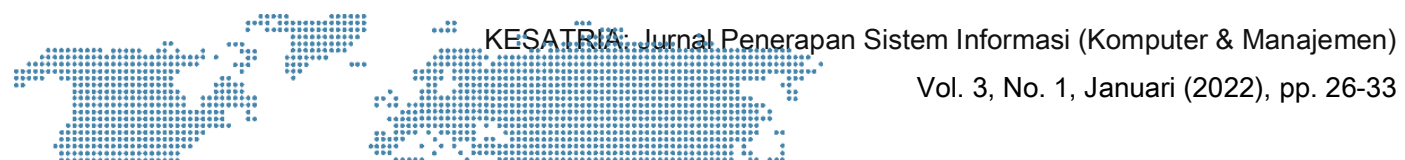

adâtait dalam menyampiakan cerita guru sekolah minggu tidak memiliki alat peraga

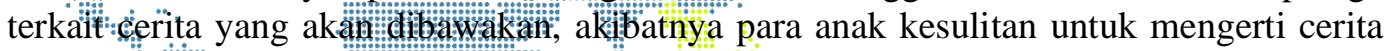
yang dibawäkan oleh gur w ataut" pengajar, dan kadang membuat anak sekolah mingu

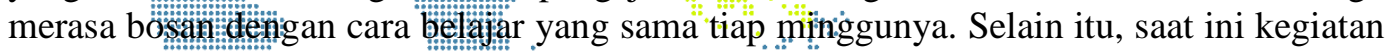
belajar mengajar di sekolah minggu juga untuk isenentara waktu ditiadakan dikarenakan pandemi Coxid 19 sehingga ${ }^{2}$ nak-anak hanya dapattolajar dan ibadah dirumah masingmasing.

Berdasarkän beberapa masalah yang diuraikan sebelumnya, maka dalam penelitian ini, peneliti berinisiatif untuk merancang aplikasi media belajar yang diharapkan dapat membantu guru untuk memberikan materi atau cerita bagi para anak di Gereja Toraja Jemaat Ora Et Labora Lagia dan juga aplikasi ini dapat menjadi solusi alternatif untuk membantu anak-anak sekolah minggu belajar agama dirumah masing-masing. Dari aplikasi media pembelajaran yang dibangun sekiranya dapat mengefisienkan proses belajar mengajar baik digereja maupun dirumah, serta membuat anak-anak sekolah minggu lebih tertarik untuk belajar. Adapun yang menjadi rumusan masalah dari penelitian ini yaitu bagaimana merancang dan membangun aplikasi media pembelajaran Pendidikan agama Kristen bagi anak-anak sekolah minggu berbasis android yang menarik dan menyenangkan, dengan tujuan mengimplementasikannya.

\section{Metodologi Penelitian}

\subsection{Waterfall}

Metode waterfall adalah salah satu metode pengembangan sistem yang tahap pengembangannya dilakukan secara bertahap, mulai dari tahap perancangan hingga tahap akhir yaitu tahap pemeliharaan [2].

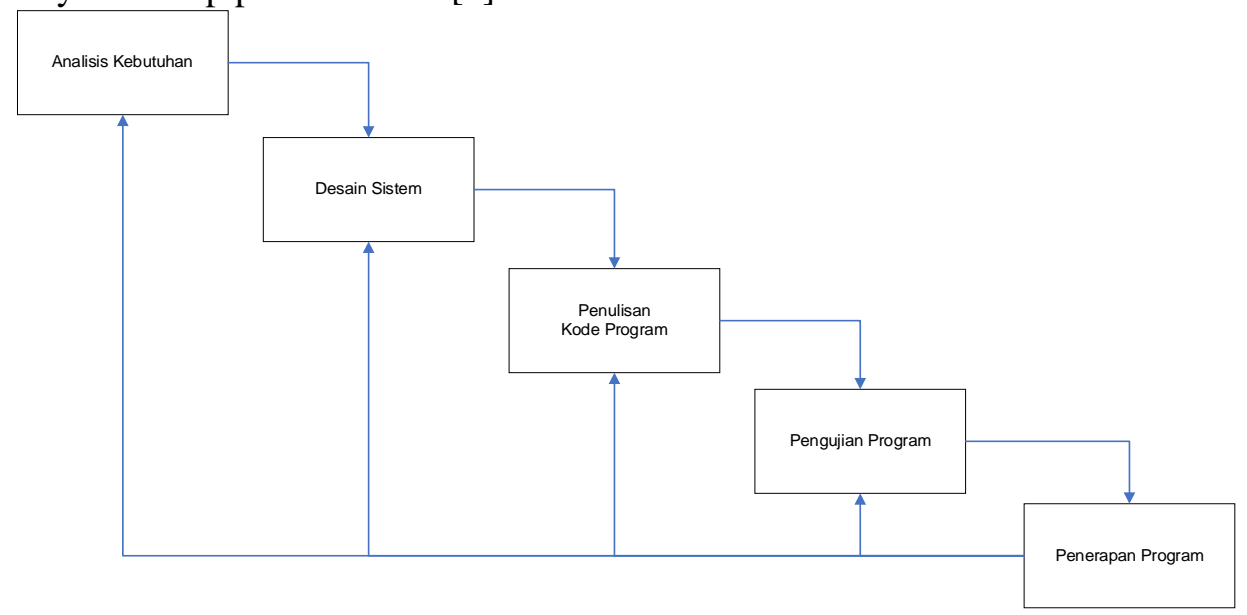

Gambar 1. Metode Waterfall

\subsection{Prototype}

Prototype merupakan salah satu metode pengembangan sistem proses pengembangannya terbilang cepat serta pengujian sistem dilakukan bisa secara berulangulang [2]. Berikut perbandingan sistem waterfall dan prototyping dalam tahapan pengembangan sistem yang akan ditunjukkan pada Tabel 1 .

Tabel 1. Perbandingan Tahap Pengembangan

\begin{tabular}{|l|l|l|}
\hline \multicolumn{1}{|c|}{$\begin{array}{c}\text { Tahapan } \\
\text { Pengembangan }\end{array}$} & \multicolumn{1}{|c|}{ Waterfall } & \multicolumn{1}{c|}{ Prototyping } \\
\hline $\begin{array}{l}\text { Perencanaan } \\
\text { system }\end{array}$ & Berawal dari Kebutuhan & Berawal dari Kebutuhan \\
\hline Analisis Sistem & $\begin{array}{l}\text { Kebutuhan data di analisis di } \\
\text { awal }\end{array}$ & $\begin{array}{l}\text { Kebutuhan data dapat ditambah } \\
\text { dan dikurangi disesuaikan } \\
\text { dengan permintaan pengguna }\end{array}$ \\
\hline
\end{tabular}




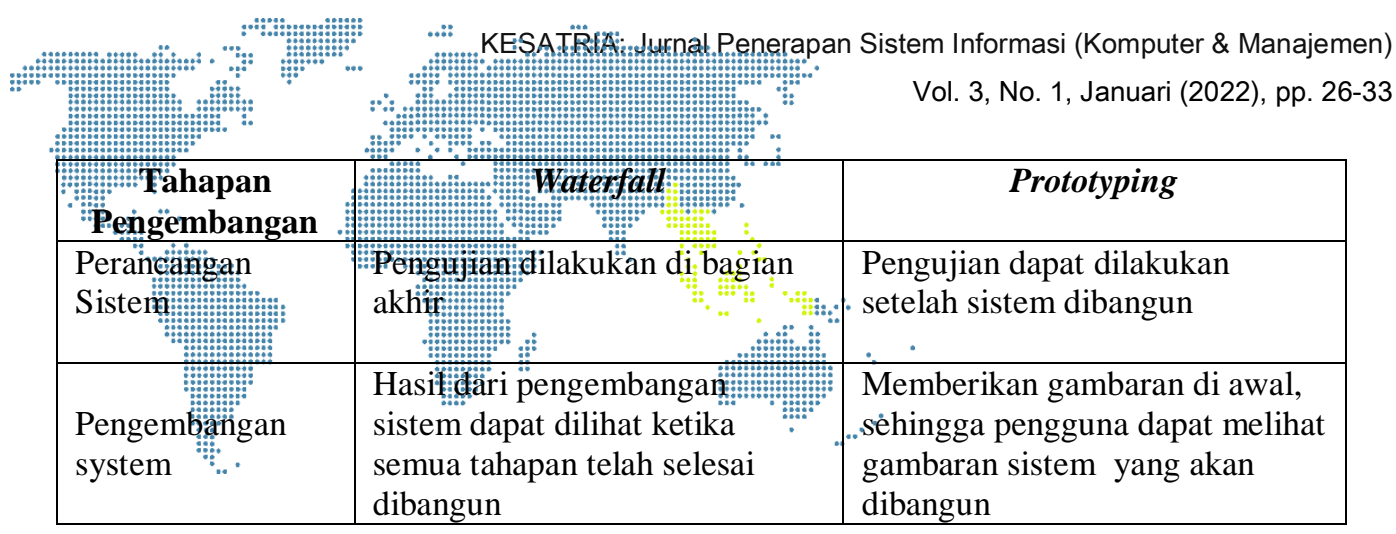

Setelah megetahui kelebihan dan kekurangan dari metode waterfall dan prototyping penulis memilih metode waterfall untuk pengembangan sistem yang akan dibuat, memilih metode waterfall karena sesuai dengan penelitian yang akan dilakukan saat pengembangan sistem, seperti kebutuhan data dianalisis diawal, melakukan testing saat tahapan model selesai.

\subsection{Tahapan Penelitian}

Tahapan penelitian yang dilakukan dalam penelitian dapat dilihat pada Gambar 1 .

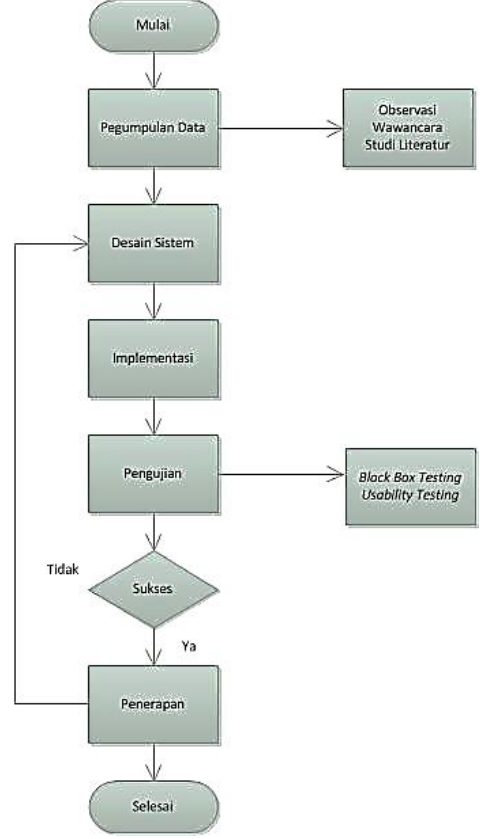

Gambar 2. Diagram alir penelitian

\subsection{Analisis Sistem yang Berjalan}

Metode pembelajaran pada sekolah minggu yaitu dengan menjelaskan materi secara langsung kepada anak-anak sekolah minggu tanpa menggunakan alat peraga atau media pembelajaran. Analisis system yang berjalan pada pelayanan sekolah minggu dapat diihat pada Gambar 3.

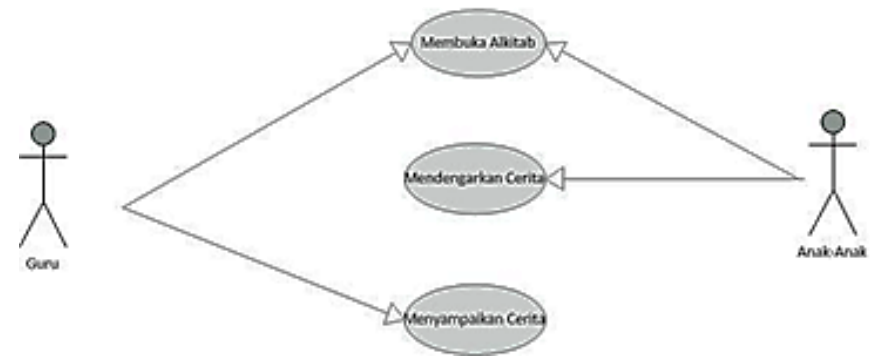

Gambar 3. Analisis yang Berjalan 


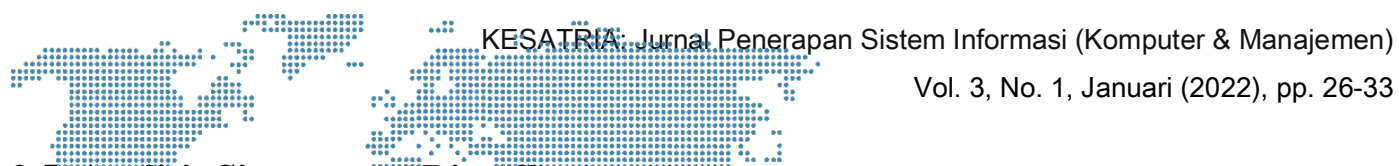

\subsection{Anatisis Sistem yañg Diusulikan}

Dragiam use case

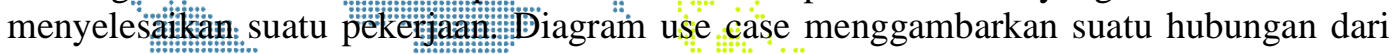
satu actor inaulebih dengan is sistem informasi yang:akan diciptakan. Use Case Diagram

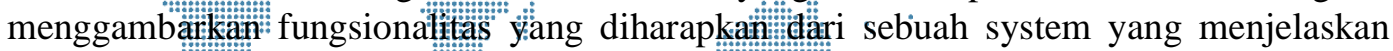
keseluruhan kerja system secara garis besar : iengan mempresentasikan interaksi antara actor yang êtibuat, serta memberikan gambaran fungsi-fungsi pada system tersebut [3]. Bentuk use case diagram dapat dilihat pada Gambar 4.

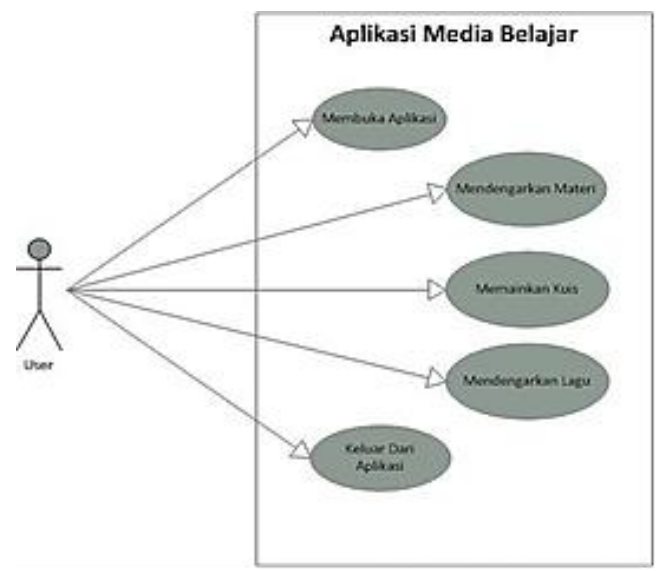

Gambar 4. Analisis Sistem yang Diusulkan

\subsection{Unified Modeling Language (UML)}

UML adalah salah satu standar bahasa yang banyak digunakan di dunia industri untuk mendefinisikan requirement, membuat analisis dan desain, serta menggambarkan arsitektur dalam pemrograman beriorentasi objek. UML menyediakan serangkaian gambar dan diagram yang sangat baik. Beberapa diagram menfokuskan diri pada ketangguhan teori object oriented, dan sebagian lagi memfokuskan pada detail rancangan dan konsentrasi. Suatu dimasukkan sebagai sarana komunikasi antar teori programer maupun dengan pengguna [4].

\subsection{Android}

Android merupakan sistem operasi mobile berbasis kernel Linux yang dikembangkan oleh Android Inc dan kemudian diakuisisi oleh Google. Sistem operasi androis bersifat open source sehingga para programmer dapat meciptakan suatu aplikasi dengan mudah. Kehadiran android diperkirakan mampu bersaing dengan sistem operasi mobile lainnya seperti blackberry, symbian dan iphone. Salah satu keunggulan android terletak pada bervariasinya merek ponsel yang mengadopsi sistem operasi ini [5].

\subsection{Adobe Flash}

Adobe Flash adalah software yang dapat digunakan untuk membuat animasi disertai gambar, video, teks, bagan, dan suara. Ada beberapa alasan memilih flash sebagai media presentasi, yaitu karena flash memiliki kelebihan, antara lain hasil akhir file flash memiliki ukuran yang lebih kecil (setelah dipublish), Flash mampu mengimpor hampir semua file gambar dan file-file audio sehingga presentasi dengan flash dapat lebih hidup, animasi dapat dibentuk, dijalankan, dan dikontrol. Flash dapat membentuk file executable (*.exe) sehingga dapat dijalankan pada PC (Personal Computer) manapun tanpa harus menginstal terlebih dahulu program flash [6].

\subsection{Corel Draw}

Corel Draw merupakan drawing software yang sangat terkenal luas. Sebuah software 


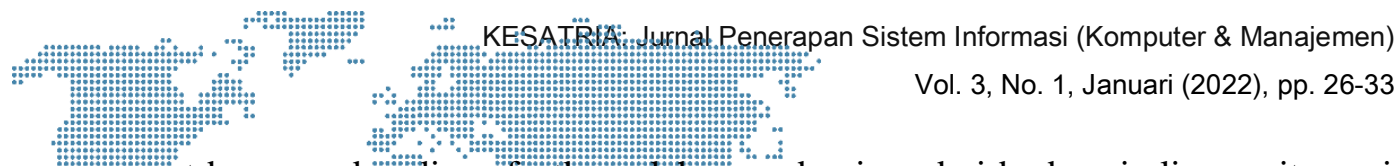

yange sangat berguna dan dimanfacatkan ofeh para desainer dari berbagai aliran yaitu seni murnf, desain logo, desaim buku dan tsebagainya. "Đatum perelitian ini, penulis menggunakan CorelDraw versi X7 sebagai sơfow wateituntuk mentidesain gambar [7].

\subsection{Pengüian Sistem}

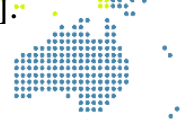

Pengujian: white box adalah suatu cara untuk méngevaluasi suatu perangkat lunak yang dilakukan dengan memperhatikan modul sehingga dapat meneliti dan menganalisa kode dari program yang di buat apakah memiliki kesalahan. Jika keluaran yang dihasilkan tidak sesuai dengan yang diinginkan maka dilakukan pengecekan kembali terhadap kode-kode program [8]. Kekurangan dari pengujian white box yaitu melibatkan sumberdaya pada perangkat lunak yang jenisnya besar, sehinggan dianggap boros. Sedangkan, pengujian black box berpacu pada bentuk tampilan dari suatu software. Pada penelitian ini penulis mengunakan pengujian Black Box karena penulis hanya berfokus pada fungsionalitas dari sistem yang dibangun.

\section{Hasil dan Pembahasan}

Berdasarkan penelitian yang telah dilakukan melalui observasi dan wawancara terhadap dua guru pendamping sekolah minggu, peneliti mendeskripsikan pokok permasalahan yang terdapat di lokasi penelitian.

\subsection{Implementasi Sistem}

Implementasi sistem adalah suatu sistem proses untuk menempatkan sistem yang baru ke dalam sistem yang sudah ada, atau dengan kata lain implementasi merupakan prosedure yang dilakukan untuk menyelesaikan desain yang ada.

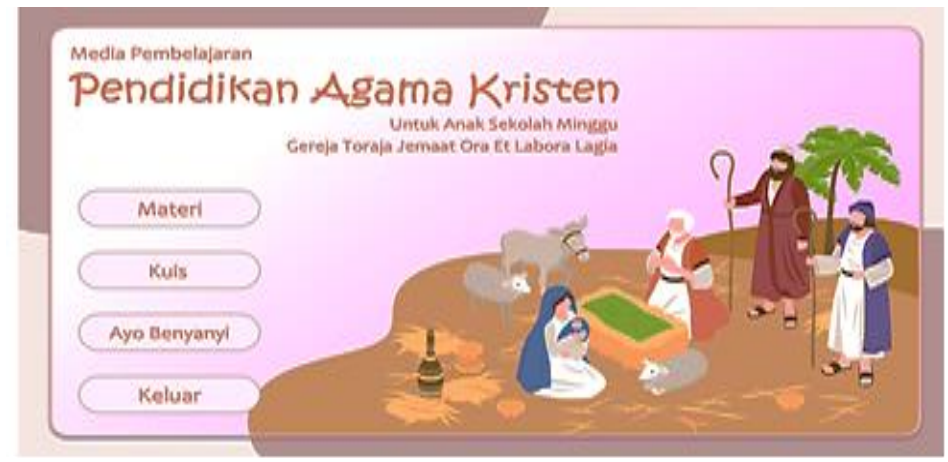

Gambar 5. Tampilan menu utama

Dalam tampilan menu utama berisi tombol materi, tombol kuis, tombol ayo bernyanyi, serta tombol keluar. Untuk setiap tombol memiliki halaman berbeda dalam menampilkan informasi serta tampilan aplikasi.

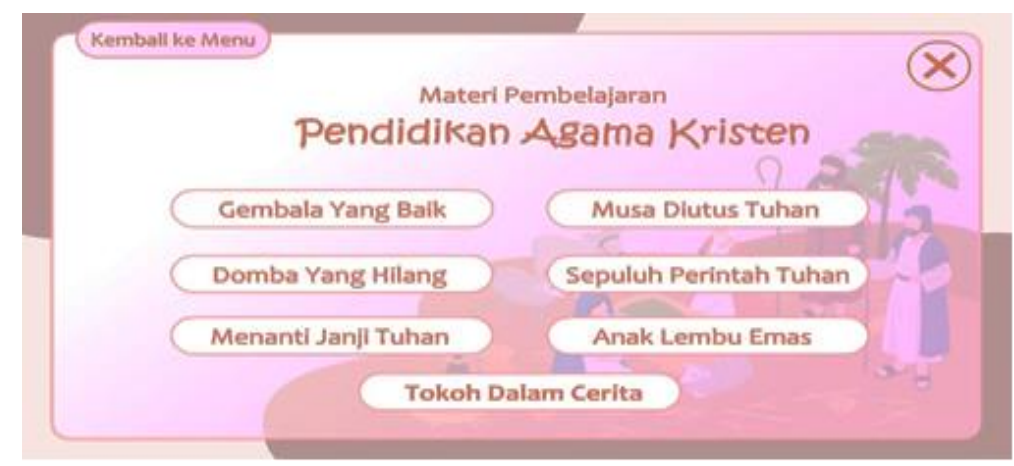

Gambar 6. Tampilan isi menu materi 


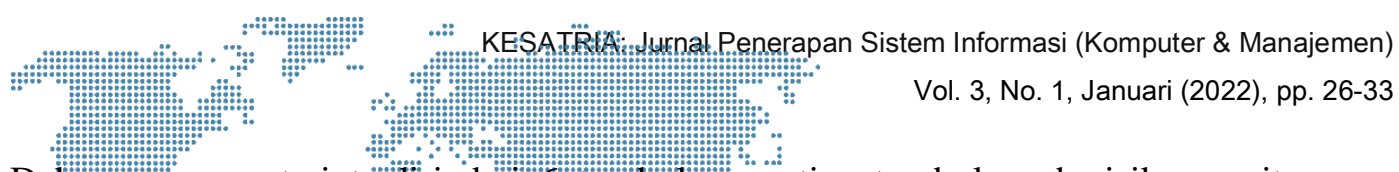

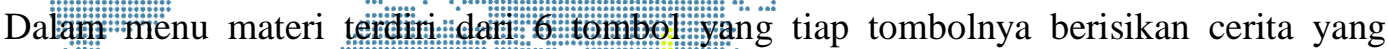

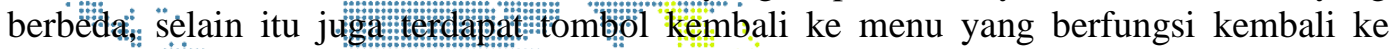

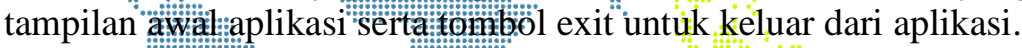

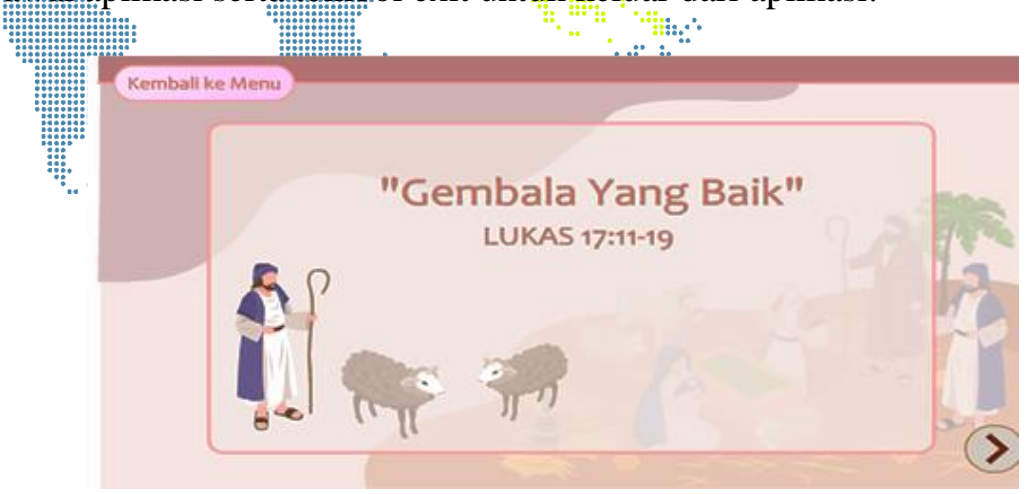

Gambar 7. Tampilan isi pendahuluan materi

Dalam halaman pendahuluan materu terdapat 2 tombol yaitu tombol panah ke kanan dengan fungsi untuk lanjut ke dalam cerita, serta tombol kembali ke menu dengan fungsi kembali ke menu materi.

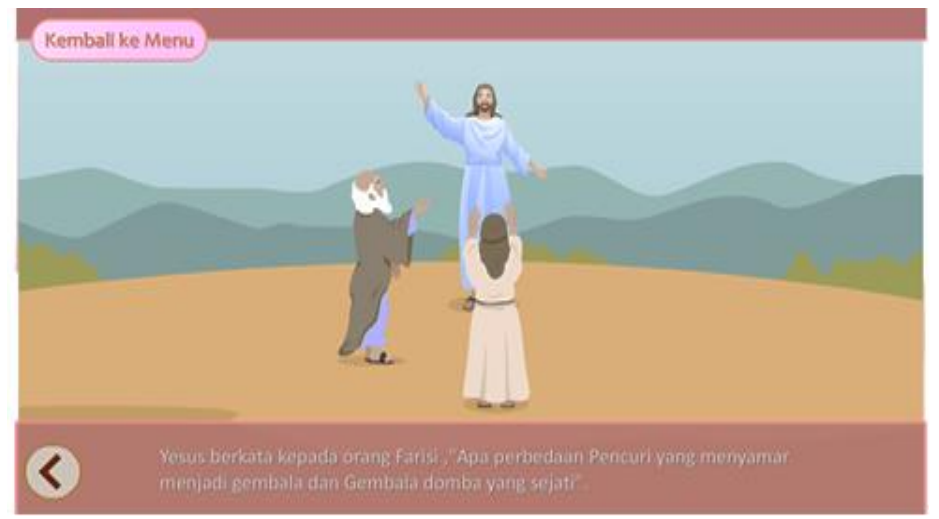

Gambar 8. Tampilan isi materi

Pada tampilan isi materi terdapat 2 tombol yaitu tombol panah ke kiri atau back ke tampilan sebelumnya, dan tombol kembali ke menu yang berfungsi untuk kembali ke tampilan utama.

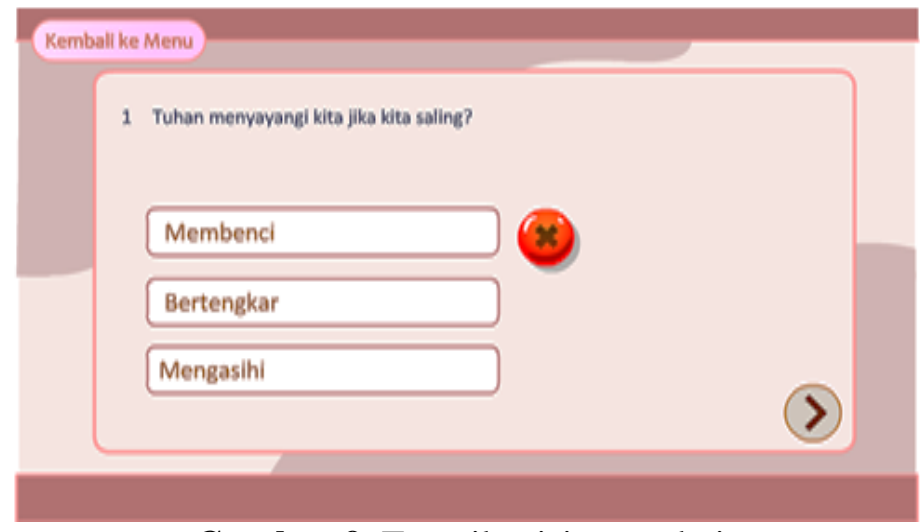

Gambar 9. Tampilan isi menu kuis

Pada menu kuis terdapat 2 tombol yaitu tombol panah ke kanan atau next ke soal selanjutnya dan tombol kembali ke menu yang berfungsi untuk kembali ke menu utama. 


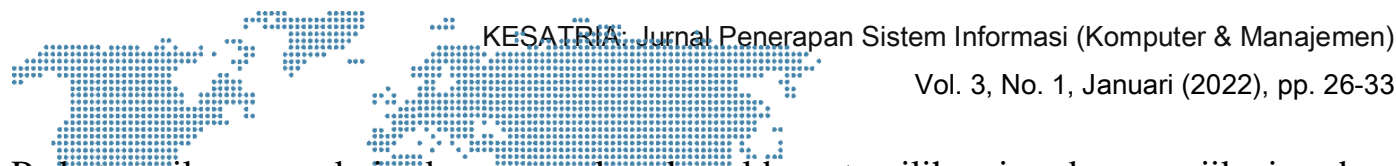

Padăa tampilan menu kư̂śd yang dipilih salah mäka aken nutucu

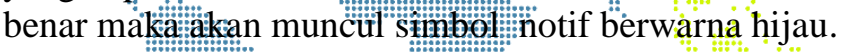

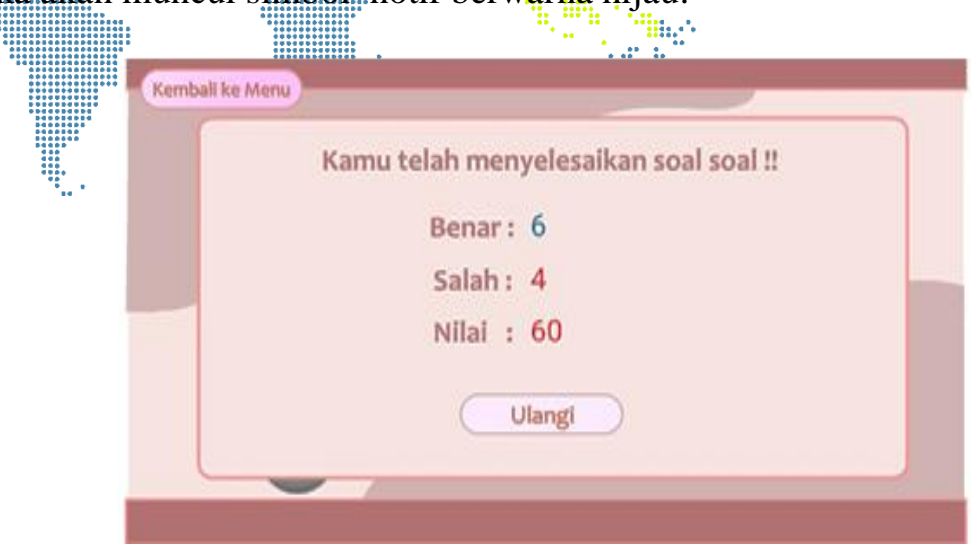

Gambar 10. Tampilan isi hasil kuis

Pada tampilan hasil kuis terdapat 2 tombol yaitu tombol Ulangi yang berfungsi untuk kembali mengulang kuis, dan tombol kembali ke menu yang berfungsi untuk kembali ke tampilan halaman utama. Selain dua tombol tersebut juga terdadpat informasi kuis yaitu informasi jumlah benar dan jumlah jawaban yang salah serta nilai yang diperoleh.

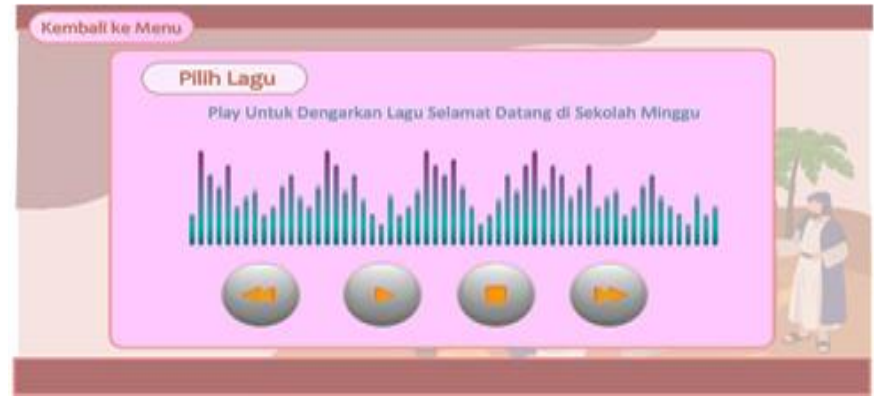

Gambar 11. Tampilan isi menu ayo bernyanyi

Pada menu ayo bernyanyi terdapat beberapa tombol yaitu tombol panah ke kiri yang befungsi kembali ke lagu sebelumnya, tombol next yang berfungsi melangkah ke lagu berikutnya, tombol stop yang berfungsi untuk berhenti, tombol play yang berfungsi untuk memutar lagu, tombol pilih lagu berfungsi untuk menampilkan pilihan lagu

\subsection{Pengujian}

Tabel 2. Halaman utama

\begin{tabular}{|l|l|c|c|}
\hline \multirow{2}{*}{ Nama Tombol } & \multirow{2}{*}{ Fungsi } & \multicolumn{2}{c|}{ Pengujian } \\
\cline { 3 - 4 } & & Sesuai & $\begin{array}{c}\text { Tidak } \\
\text { sesuai }\end{array}$ \\
\hline Tombol masuk menu materi & Masuk menu materi & $\checkmark$ & \\
\hline Tombol masuk menu kuis & Masuk menu kuis & $\checkmark$ & \\
\hline Tombol masuk menu ayo bernyanyi & Masuk menu lagu & $\checkmark$ & \\
\hline
\end{tabular}

Tabel 3. Menu materi

\begin{tabular}{|l|l|c|c|}
\hline \multirow{2}{*}{ Nama Tombol } & \multicolumn{1}{c|}{ Fungsi } & \multicolumn{2}{c|}{ Pengujian } \\
\cline { 3 - 4 } & \multicolumn{1}{c|}{ Sesuai } & Tidak sesuai \\
\hline Tombol materi gembala yang baik & Tombol materi gembala yang baik & $\checkmark$ & \\
\hline Tombol kembali ke menu materi & Kembali pilih materi & $\checkmark$ & \\
\hline Tombol kembali ke menu awal & Kembali ke menu awal & $\checkmark$ & \\
\hline
\end{tabular}




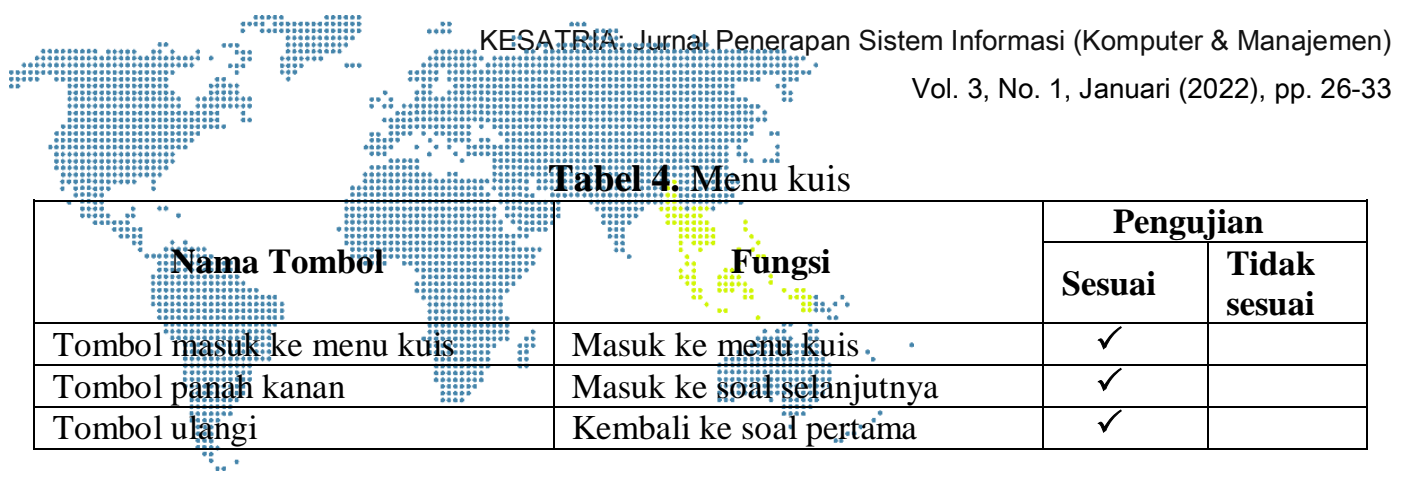

Tabel 5. Menu ayo bernyanyi

\begin{tabular}{|l|l|c|c|}
\hline \multirow{2}{*}{ Nama Tombol } & \multicolumn{1}{c|}{ Fungsi } & \multicolumn{2}{c|}{ Pengujian } \\
\cline { 3 - 4 } & & Sesuai & $\begin{array}{c}\text { Tidak } \\
\text { sesuai }\end{array}$ \\
\hline Tombol kembali ke menu & Kembali ke menu utama & $\checkmark$ & \\
\hline Tombol next & Memutar lagu selanjutnya & $\checkmark$ & \\
\hline Tombol back & Kembali ke lagu sebelumnya & $\checkmark$ & \\
\hline Tombol play & Memainkan lagu & $\checkmark$ & \\
\hline Tombol stop & Berhenti memutar lagu & $\checkmark$ & \\
\hline
\end{tabular}

\section{Kesimpulan}

Dari penelitian dan pengujian yang telah peneliti lakukan maka peneliti menyimpulkan:

1) Berdasarkan validasi pada ahli media, media pembelajaran memperoleh nilai $82 \%$, sehingga berdasarkan interprestasi skala likert media pembelajaran masuk dalam kategori sangat layak untuk dijadikan media alternative atau sebagai media pendamping dalam pembelajaran pendidikan agam Kristen.

2) Berdasarkan validasi pada orang tua, media pembelajaran memperoleh nilai $92,8 \%$, sehingga berdasarkan interprestasi skala likert media pembelajaran masuk dalam kategori sangat layak untuk dijadikan sebagai media yang dapat menarik minat belajar anak-anak sekolah minggu.

3) Berdasarkan hasil pengujian black box media pembelajaran yang dibangun tidak mengalami eror saat digunakan dan semua tombol berfungsi dengan baik.

\section{Daftar Pustaka}

[1] Lisda dan Seto Mulyadi, "Pembuatan Animasi Pembelajaran Berbasis Multimedia Mata Kuliah Psikologi Perkembangan Menggunakan Adobe flash cs3," Universitas Gunadarma Depok, 2014.

[2] R. dan A. A. D. Susanto, "Perbandingan Model Waterfall Dan Prototyping Untuk Pengembangan Sistem Informasi," J. Maj. Ilm. Unikom, vol. 14, no. 1, 2016.

[3] M. R. Manalu, "Implementasi Sistem Informasi Penyewaan Mobil Pada Cv. Btn Padang Bulan Dengan Metode Waterfall," J. Mantik Penusa, vol. 18, no. 2, 2015.

[4] A. Hendini, "Permodelan UML Sistem Informasi Monitoring Penjualan Barang," Khatulistiwa, vol. 4, no. 2, 2016, [Online]. Available: https://ejurnal.bsi.ac.id/\%09ejurnal/index.php/khatulistiwa/article/view/1262/1027.

[5] Enterprise Jubilee, Mengenal Dasar-Dasar Pemograman Android. Jakarta: PT. Alex Media Komputindo, 2015.

[6] F. H. dkk Rahmaibu, "Pengembangan Media Pembelajaran Menggunakan Adobe Flash Untuk Meningkatkan Hasil Belajar PKn,” J. Kreat. Sept. 2016, [Online]. Available: https://journal.unnes.ac.id/nju/index.php/kreatif/article/download/9362/6128.

[7] Suharmawan, "Modul 1.01 Desain Grafis CorelDraw Pengenalan," Ngawi, 2016. [Online]. Available: https://docplayer.info/67117533-Modul-materi-corel-draw-x7-di-susun-olehsuharmawan-amd-graf.html.

[8] H. Mustaqbal, M. S., Firdaus, R. F., \& Rahmadi, "Pengujian Aplikasi Menggunakan Black Box Testing Boundary Value Analysis (Studi Kasus: Aplikasi Prediksi Kelulusan Snmptn)," J. Ilm. Teknol. Inf. Terap., vol. 1, no. 3, 2015. 